\title{
Pollution effects in Visakhapatnam harbour, India: an overview of 23 years of investigations and monitoring
}

\author{
A. V. Raman \\ Division of Marine Biology, Department of Zoology, Andhra University; Waltair, \\ Visakhapatnam 530 003, India
}

\begin{abstract}
Visakhapatnam Harbour, a semi-enclosed water body on the east coast of India, is subject to a high degree of pollution caused by industrial and urban wastes. Studies carried out during the last twenty years or so at 6 selected stations in the harbour revealed appreciable hydrographic and biotic changes. Over the years, the concentration of nitrites (max. $5 \mathrm{mg} / \mathrm{l}$ ) and phosphates $(9.6 \mathrm{mg} / \mathrm{l})$ has increased. Dissolved oxygen registered all-time-high values (max. $21.6 \mathrm{mg} / \mathrm{l}$ ) caused by periodic outbursts of phytoplankton, notably, Skeletonema costatum and other species. Benthic conditions have also changed and only certain pollution-tolerant species (e.g. Capitella capitata) inhabited the bottom sediments that contained a heavy load $(2.5 \%)$ of organic matter. In the harbour, increased pollution led to the disappearence of stenoecious species and their replacement with other forms known for their tolerance to pollution. The paper describes the major changes which have occurred in water quality and organisms in the harbour as a result of pollution increase during the last two decades.
\end{abstract}

\section{INTRODUCTION}

Ganapati (1969) and Ganapati \& Raman (1973) gave a brief account of the topography and some aspects of pollution in Visakhapatnam harbour, consequent to the rapid industrialisation and urbanisation of the city. Since the publication of the above papers, the harbour has gone through a massive expansion programme, including the construction of a $2 \mathrm{sq} \mathrm{km}$ outer harbour, which brought in its wake further reduction in water circulation, accentuating stagnation. The land-locked situation of the harbour and the consequent limitations of natural flushing processes have largely contributed to the exposure of plant and animal communities to environmental pollution stresses from a variety of industrial installations which have sprung up in the environs of the harbour. Added to this the harbour also receives most of the city's domestic effluents which are considerable, owing to the rapidly growing urban population. With a view to finding out the overall changes in relation to pollution, studies on the physico-chemical and biological characteristics of water and sediments at selected stations in the harbour have been undertaken since 1968. The present paper deals with some of these findings.

\section{MATERIAL AND METHODS}

Altogether six stations, located along a decreasing gradation of pollution, were chosen for the study (Fig. 1). St.Va represents the most polluted area, since the bulk of the 


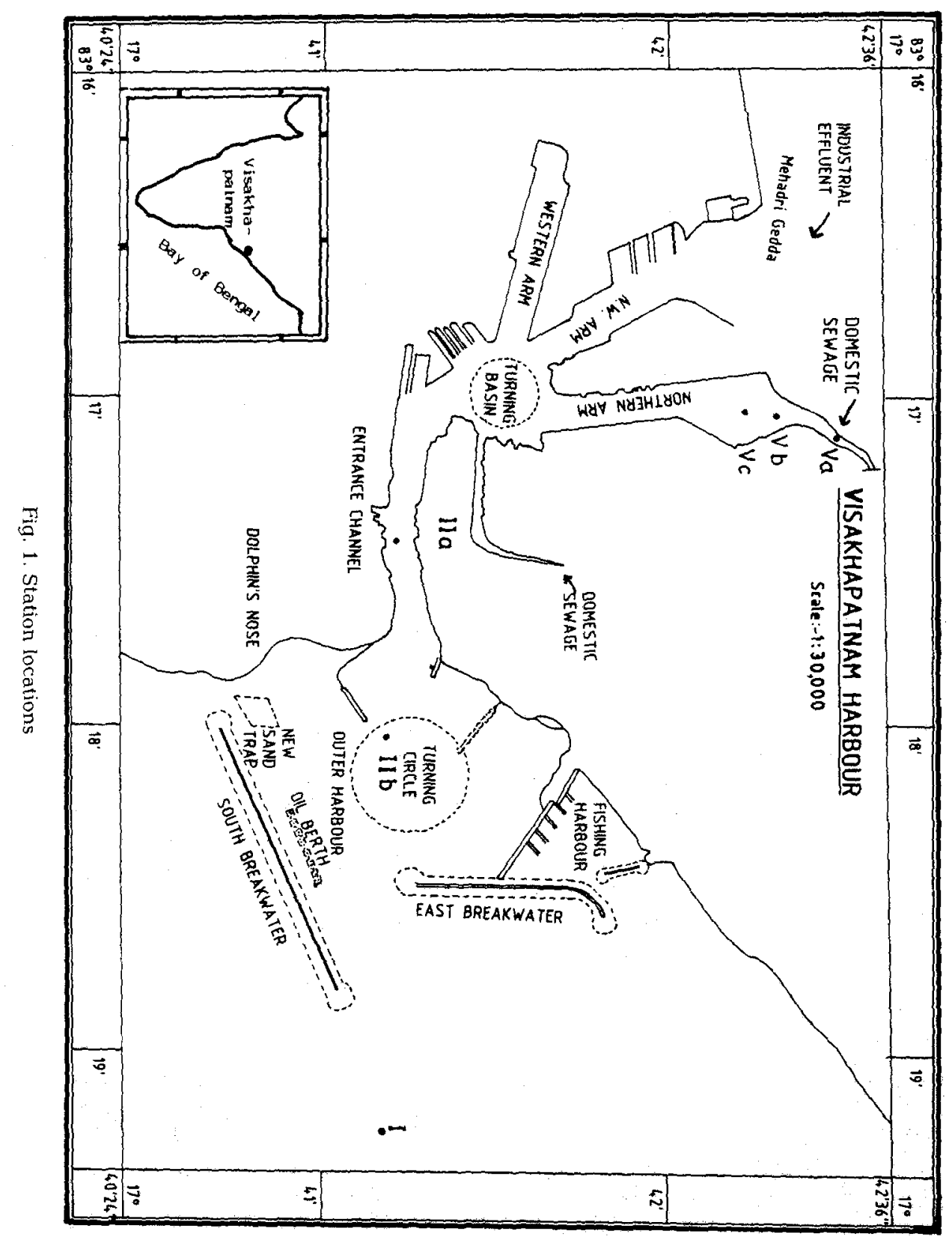


city's sewage is emptied here. Stations Vb and Vc are located downstream. St.IIa is in the entrance channel and St.IIb in the outer harbour, midway between the inner harbour and open sea. St.I is the cleanest of all stations and is located in the open sea (depth 35-40 m).

All observations were made during low tide. While it was not always possible to study the entire area, two major investigations, one each in 1976 and 1985-1987 were undertaken. During these years, observations were made at selected stations at periodic monthly (1976) and fortnightly (1985-1987) intervals. In order to describe the interannual variations, data collected at a single location (St.IIa), based on intensive (tri-weekly), fortnightly and monthly observations, were used. While the surface samples were obtained with the help of a polythene bucket, a reversing Nansen bottle was used for bottom water.

The water-quality parameters included turbidity (Hellige's Turbdimeter), secchi-disc transparency, salinity (Knudsen method), dissolved oxygen (Winkler Azide modification), B.O.D. (Standard Methods, 1971) and inorganic nitrogen, phosphorus and silicate according to Strickland \& Parsons (1968), and Manual of Methods in Aquatic Environment Research, FAO (1975). In addition, sediment texture (Holme \& McIntyre, 1971) and its organic content (Gaudette et al., 1974) were estimated. Biological investigations included an examination of phytoplankton and benthic polychaetes. For phytoplankton, both unit samples (1 litre volume) and net hauls were collected and their densities (nos/ml) determined according to UNESCO (Sournia [Ed.], 1978). In addition, estimations on chlorophyll $a, b$ and $c$ were made, following Richards \& Thompson (1952). For sampling benthos, a Petersen grab $\left(0.05 \mathrm{~m}^{2}\right)$ was used, as well as a metal quadrate $\left(0.01 \mathrm{~m}^{2}\right)$ for samples collected intertidally.

The climate of Visakhapatnam is governed by its location in the tropics (latitude: $17^{\circ} 40^{\prime} 30^{\prime \prime}$ and $17^{\circ} 48^{\prime}$ North; longitude: $83^{\circ} 16^{\prime} 25^{\prime \prime}$ and $83^{\circ} 21^{\prime} 30^{\prime \prime}$ East). The mean monthly values of day-temperature range from a minimum of $27.7^{\circ} \mathrm{C}$ (January) to a maximum of $34.0^{\circ} \mathrm{C}$ (May). The total rainfall exceeds $1000 \mathrm{~mm}$, nearly $80 \%$ of which occurs during the June-November period.

Tides are chiefly semi-diurnal and have a mean range of $0.9 \mathrm{~m}$. There is considerable freshwater influx into the harbour through a monsoon-fed stream known as "Mehadrigedda". Mehadrigedda is also the principal source of industrial effluents into the harbour, since this river is used as a conduit for the discharge of wastes. In the harbour, bordering the north and northwest periphery, there are extensive low-lying swampy areas with mangrove and scrub vegetation.

\section{RESULTS AND DISCUSSION}

\section{Water quality}

Investigations on water quality revealed appreciable differences between the harbour environment subject to pollution, and the unaffected open sea location (Table 1). Inside the harbour (Stations Vc, IIa and IIb), where the effects of pollution are relatively. high, the waters are distinctly characterized by an overall range of (median values) high temperature $\left(27.5-30.0^{\circ} \mathrm{C}\right)$, poor transparency $(0.6-2.5 \mathrm{~m})$, high turbidity $(6.75-23.0 \mathrm{ppm}$ ), varying salinity (range $1.98-34.74 \%$ ), generally low pH $(5.8-8.9)$, widely fluctuating dissolved oxygen $(0-21.6 \mathrm{mg} / \mathrm{l})$ and high inorganic nitrogen (ammonia 


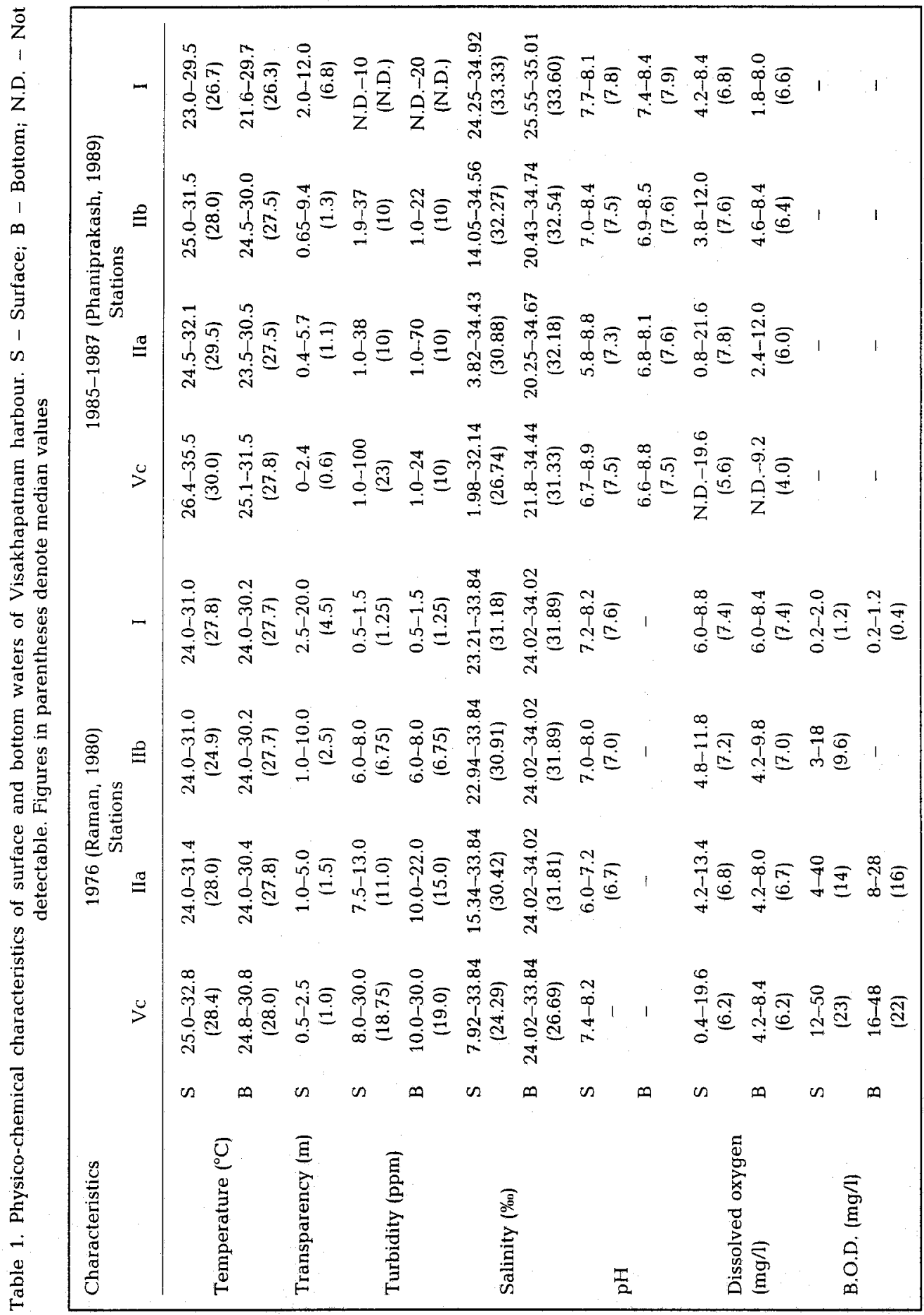




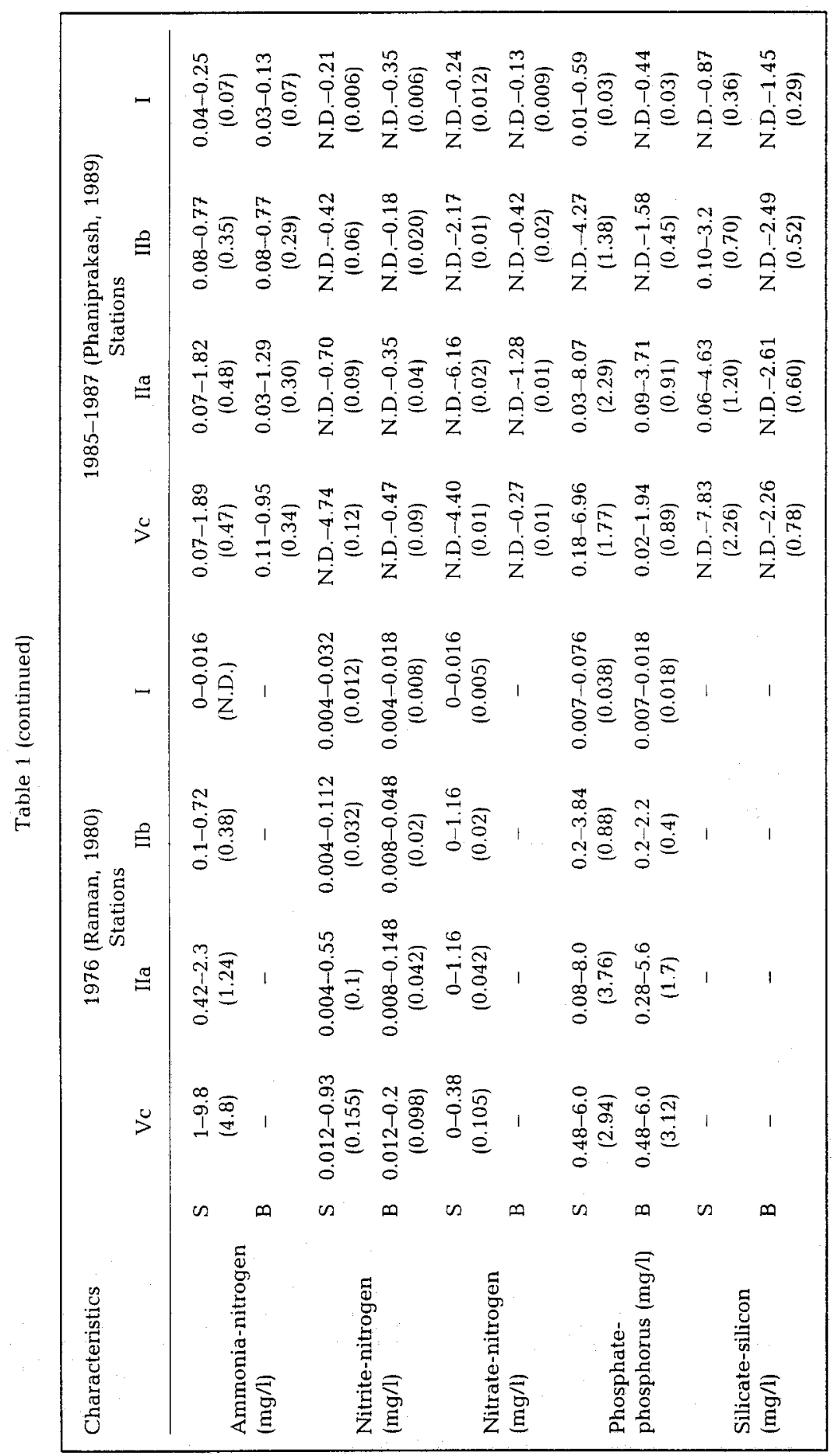




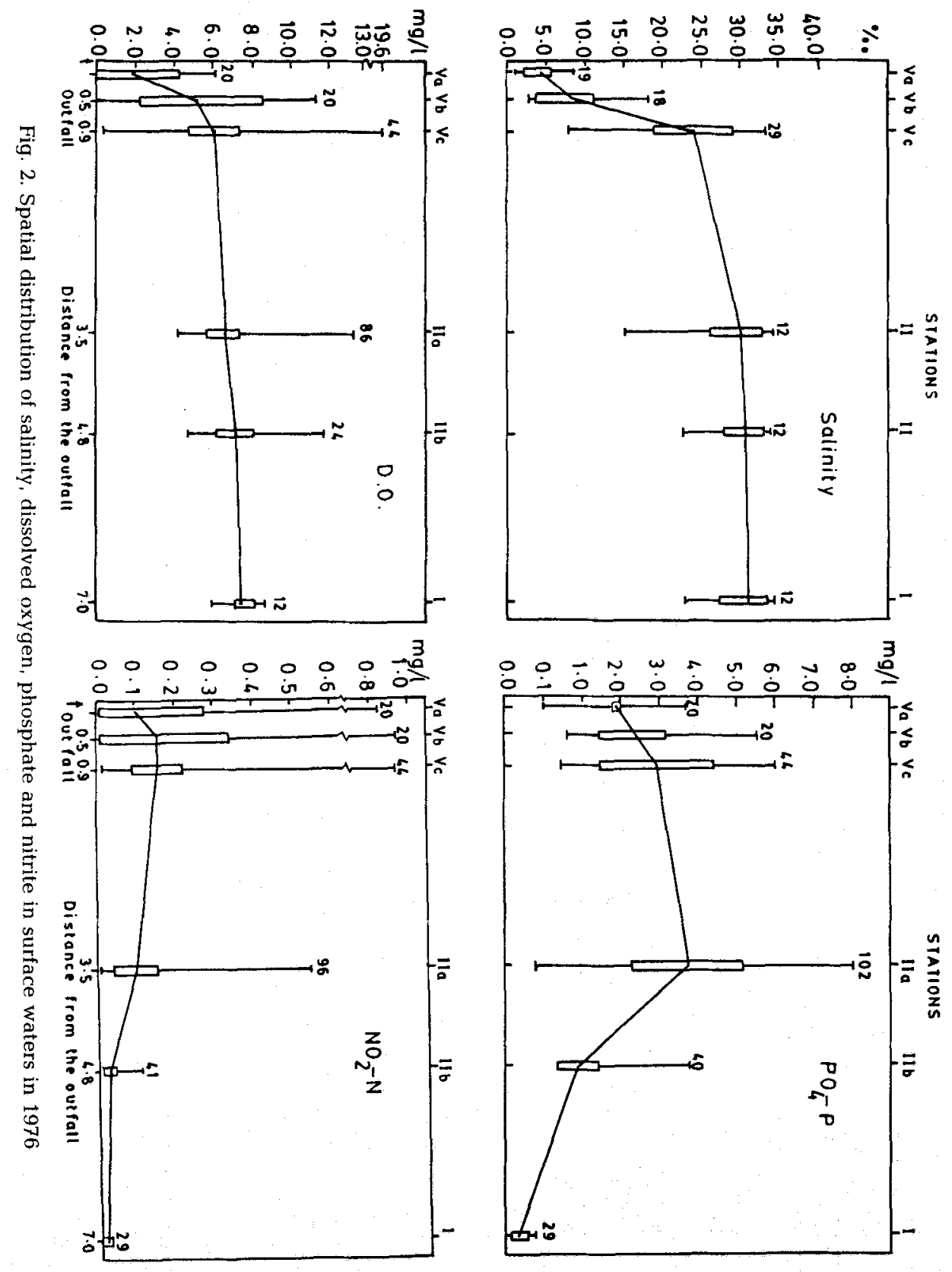


$0.35-4.8 \mathrm{mg} / \mathrm{l}$; nitrite $0.02-0.155 \mathrm{mg} /$; nitrate $0.01-0.105 \mathrm{mg} / \mathrm{l})$, phosphate $(0.4-3.76$ $\mathrm{mg} / \mathrm{l})$ and silicate $(0.52-2.26 \mathrm{mg} / \mathrm{l})$ as against near-normal conditions in the open sea (St.I). Here, water transparency (median value) is more: $4.5-6.8 \mathrm{~m}$; turbidity negligible, 0-1.25 ppm; pH 7.6-7.9; salinity, 23.21-34.92\%; dissolved oxygen, 6.6-7.4 mg/l, and inorganic nitrite, phosphate and silicate levels remaining comparatively low $(<0.01 \mathrm{mg} / \mathrm{l})$. Figure 2 shows the spatial distribution (range and median) of salinity, dissolved oxygen and inorganic nutrients in surface waters, observed away from the pollution source.

During the study, it was found that the harbour waters are subject to considerable seasonal changes. In 1985-1987, surface-dissolved oxygen at St.IIa varied from a

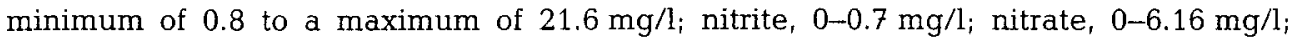
phosphate, $0-8.07 \mathrm{mg} / \mathrm{l}$ and silicate, $0.16-3.2 \mathrm{mg} / \mathrm{l}$. However, day-to-day variations were equally marked at this station. For example, between the 4th and 9th of September, 1985,

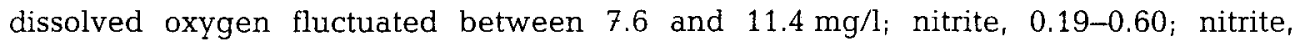
$0.02-0.09 \mathrm{mg} / \mathrm{l}$; phosphate, $2.25-3.39 \mathrm{mg} / \mathrm{l}$ and silicate, $0.98-1.76 \mathrm{mg} / \mathrm{l}$ - suggestive of strong anthropogenic effects (Phaniprakash, 1989). The investigations also revealed that the concentration of nitrites and phosphate increased appreciably over the years (Fig. 3). This is attributable to the discharge of fertiliser factory wastes (50 mgd) and untreated domestic sewage containing these substances and their persistence due to inadequate flushing. By 1982, the high nitrite (max. $5 \mathrm{mg} / 1)$ and phosphate $(9.6 \mathrm{mg} / \mathrm{l})$ observed in surface waters in the harbour (St.IIa) were evidently caused by their accumulation. In 1976, the construction of the outer harbour had completely offset any tidal action, accentuating stagnation. This period was also marked by a near-simultaneous rise in dissolved oxygen, the overall range of which increased progressively (Fig. 3), attributing to periodic outbursts of phytoplankton (Ganapati \& Raman, 1979). During later years, however, the levels of nitrite and phosphate, as well as dissolved oxygen, began to decrease.

Appreciable differences in water quality existed between the 1976 and 1985-1987 studies (Table 1). For example, water transparency has decreased (overall mean $1.67-1.0 \mathrm{~m}$ ) since 1976 . Turbidity increased relatively $(12.17-14.3 \mathrm{ppm})$, as did salinity $(29.84-30.99 \%)$ and $\mathrm{pH}(6.85-7.5)$. There was a general decrease in dissolved oxygen $(6.68-6.23 \mathrm{mg} / \mathrm{l})$ which was considerable in bottom waters at St.Vc near the sewage outfall $(2.2 \mathrm{mg} / \mathrm{l})$. The concentrations of ammoniacal nitrogen $(2.14-0.37 \mathrm{mg} / \mathrm{l})$, nitrite $(0.075-0.07 \mathrm{mg} / \mathrm{l})$, nitrate $(0.06-0.01 \mathrm{mg} / \mathrm{l})$ and inorganic phosphate $(2.13-1.28 \mathrm{mg} / \mathrm{l})$ decreased comparatively by 1985-1987. Decrease in dissolved oxygen, nitrite or nitrate, or their occasional total disappearance, indicated an onset of reducing conditions in the harbour. In the vicinity of the sewage outfall (St. Vb), $\mathrm{H}_{2} \mathrm{~S}$ is found in solution and marsh gas effervesced from the bottom when disturbed.

A number of authors emphasized chemical factors, particularly inorganic nitrogen and phosphorus, as useful for assessing pollution. In enclosed sea areas, pollution through organic sewage enriches waters with nutrients and, when present in excessive amounts, can result in the replacement of normal phytoplankton populations with noxious species, thus changing the entire biotic structure in the process known as "cultural eutrophication" (Ketchum, 1973). In the harbour under discussion, the presence of high concentrations of nitrogen and phosphorus indicated eutrophic conditions. 

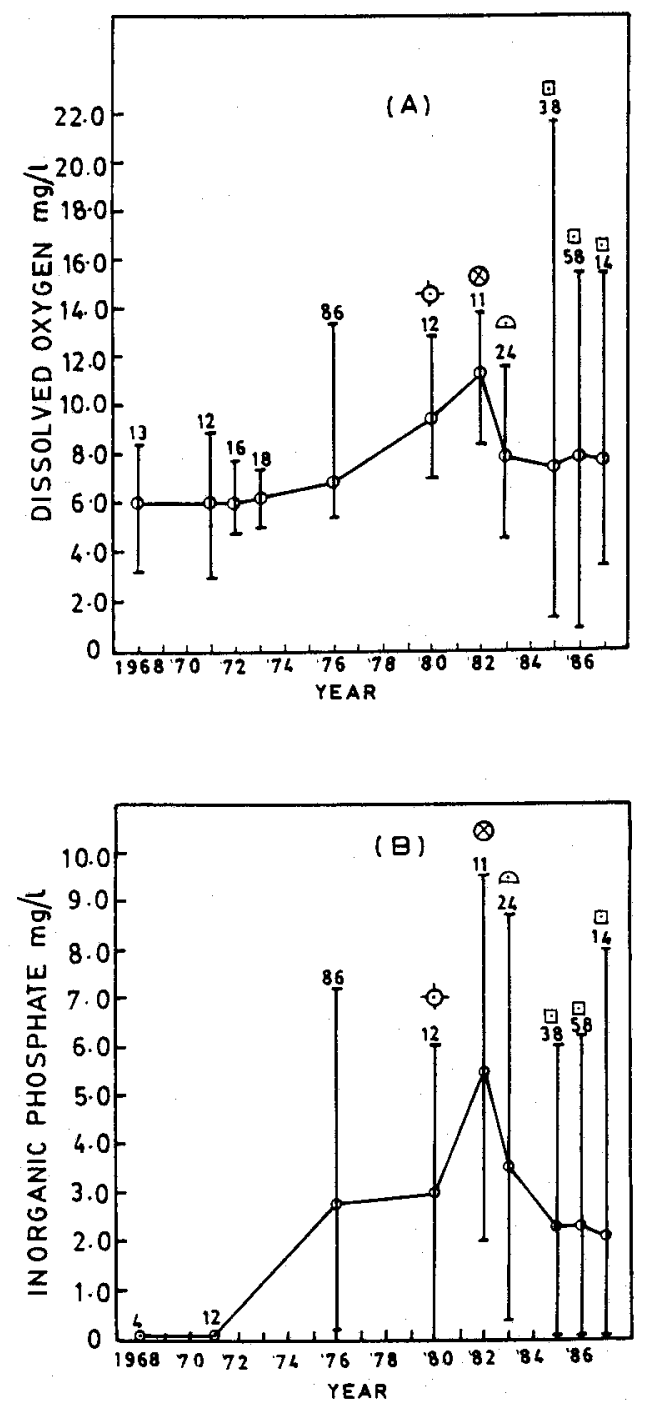

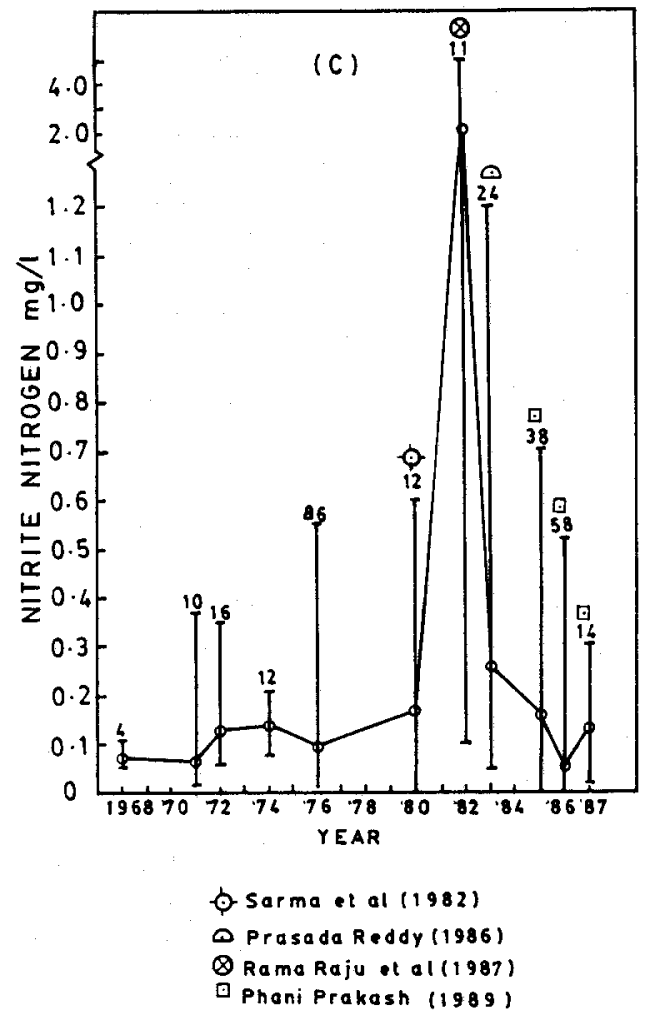

Fig. 3. Interannual variations (median and Range) in (A) dissolved oxygen, (B) inorganic phosphate and $(C)$ nitrite in surface waters at St.IIa. Figures on top denote sample size

\section{Phytoplankton}

Ganapati \& Raman (1979) and Umamahesware Rao \& Mohanchand (1988) reported Skeletonema costatum as a dominant species among the microplankton in the harbour. More recently, the investigations revealed that at $\mathrm{St.Vc}$, close to the sewage outfall, the phytoplankton consisted chiefly of flagellates, Tetraselmis sp. and Dicrateria sp., which together constituted nearly $90 \%$ of the population in the locality (Raman \& Phaniprakash, 1989a). The other species noticed were Dunaliella sp. and Eutreptia sp., and ciliates, notably Tetrahymena pyriformis, Protocruzia adhaerens, Stylonychia sp., Amphileptus sp. and Euplotes terricola. At the downstream location (St.IIa), the phytoplankton consisted of diatoms, Thalassiosira pseudonana $(50.7 \%)$, Chaetoceros diversus $(10.2 \%)$, 
Table 2. Surface chlorophyll and phytoplankton abundance (range and mean) at selected harbour locations in 1985-1986. N.D.: Not detected

\begin{tabular}{|c|c|c|c|c|}
\hline \multirow[t]{2}{*}{ Characteristics } & \multicolumn{4}{|c|}{$\begin{array}{c}\text { Stations } \\
\text { (Number of samples) }\end{array}$} \\
\hline & $\begin{array}{c}\text { Vc } \\
(23)\end{array}$ & $\begin{array}{c}\text { IIa } \\
\text { (23) }\end{array}$ & $\begin{array}{c}\mathrm{IIb} \\
(22)\end{array}$ & $\begin{array}{c}\text { I } \\
(10)\end{array}$ \\
\hline \multicolumn{5}{|l|}{$\begin{array}{r}\text { Chlorophyll } \\
\left(\mathrm{mg} \cdot \mathrm{m}^{-3}\right)\end{array}$} \\
\hline $\mathrm{Chl} \cdot a$ & $\begin{array}{c}8.00-1517.8 \\
(40.4)\end{array}$ & $\begin{array}{l}0.61-51.18 \\
(28.61)\end{array}$ & $\begin{array}{c}0.60-43.68 \\
(16.46)\end{array}$ & $\begin{array}{l}\text { N.D. }-6.55 \\
\quad(2.23)\end{array}$ \\
\hline $\mathrm{Chl} \cdot b$ & $\begin{array}{l}1.10-1096.5 \\
(18.5)\end{array}$ & $\begin{array}{l}0.98-38.31 \\
(12.55)\end{array}$ & $\begin{array}{c}0.42-27.18 \\
(7.82)\end{array}$ & $\begin{array}{l}\text { N.D. }-2.23 \\
\quad(0.89)\end{array}$ \\
\hline $\mathrm{Chl} \cdot c$ & $\begin{array}{c}1.89-15.71 \\
(55.6)\end{array}$ & $\begin{array}{l}0.69-106.86 \\
(18.66)\end{array}$ & $\begin{array}{l}\text { N.D. }-66.85 \\
\quad(17.11)\end{array}$ & $\begin{array}{c}\text { N.D. }-5.72 \\
(1.25)\end{array}$ \\
\hline $\begin{array}{l}\text { Phytoplankton } \\
\text { abundance } \\
\left(\mathrm{X} 1000 \mathrm{ml}^{-1} \text { ) }\right.\end{array}$ & $\begin{array}{l}0.54-6258 \\
(292.2)\end{array}$ & $\begin{array}{l}0.12-191.4 \\
(16.2)\end{array}$ & $\begin{array}{c}0.07-123.0 \\
(8.95)\end{array}$ & $\begin{array}{l}0.04-3.23 \\
\quad(0.92)\end{array}$ \\
\hline
\end{tabular}

Skeletonema costatum (7\%) and the flagellate Cryptomonas sp. (5.8\%). At St.IIb, characterized by its proximity to the open sea, Th. pseudonana $(57.3 \%)$ and Ch. diversus $(12.2 \%)$ constituted nearly $70 \%$ of the total population. At St.I in the open sea, where the effect of pollution was negligible, the number of phytoplankton species was at its maximum (93), of which Th. subtilis (62\%), Ch. socialis (11\%) and Asterionella japonica $(5.9 \%)$ dominated. Table 2 shows some details of the numerical abundance of phytoplankton, with information on chlorophyll $(a, b$ and $c)$ in surface waters at selected stations in the harbour noticed during 1985-1986 (Raman \& Phaniprakash, 1989b). It is evident that the harbour waters support high numbers of phytoplankton, some of which occur in bloom proportions. For example, on the 8th March 1986, the flagellate Tetraselmis sp. was found in exclusive dominance $\left(6258000 / \mathrm{ml}^{-1}\right)$ at St. $\mathrm{VC}_{\text {, when the chlorophyll }}$ $(a+b+c)$ reached an all-time-high $\left(4185 \mathrm{mg} / \mathrm{m}^{3}\right)$ (Phaniprakash, 1989). Similarly, data on short-term changes (4th to 9th September, 1985) showed that at St. Ila, total chlorophyll fluctuated between 20.85 and $94.95 \mathrm{mg} / \mathrm{m}^{3}$ in response to phytoplankton availability. In the harbour, the presence of high chlorophyll and rich phytoplankton was therefore suggestive of intense eutrophication.

Several studies have shown nanoplankton dominance to be an indicator of pollution in enclosed sea areas (Eppley \& Weiler, 1979; Mahoney \& McLaughlin, 1979; Stockner \& Cliff, 1979; Tsuruta \& Yamada, 1980; Fanuko, 1984). In the harbour under discussion, while nanoflagellates, Tetraselmis sp. and Dicrateria sp., were the characteristic inhabitants of St.Vc (close to the sewage outfall), at St.IIa where water quality marginally improved, they were replaced by Skeletonema costatum and the cryptomonad Cryptomonas sp. At the transitional outer harbour region (St.Ilb), Thalassiosira pseudonana and Chaetoceros diversus were the principal species. At St.I (open sea), where the effects of pollution are negligible, typically marine forms (Th. subtilis, Ch. socialis and Asterionella japonica) were found. 


\section{Benthic conditions}

Raman (1980) carried out a detailed investigation on benthic polychaetes in the harbour in relation to pollution. The studies conducted in 1976 revealed that the polychaetes were not only the most diverse but, in terms of population density, they often formed a high percentage $(>80 \%)$ of organisms collected. Polychaete species-abundance data (cf. Pearson \& Rosenberg, 1978) for harbour locations revealed that - whereas away from the outfall (St.Va), the total number of individuals decreased after an initial peak of "opportunists", notably the capitellid Capitella capitata - the number of species increased as the distance from the source of enrichment increased. Based on speciessimilarity-affinity indices, it was possible to distinguish three distinct polychaete assemblages, each characterizing the (polluted) inner harbour (Stations Vb, Vc and IIa); the transitional (semi-polluted) outer harbour (St.IIb) and the unaffected (unpolluted) open sea (St.I) environments (Raman \& Ganapati, 1983). At St.Va, located in the immediate vicinity of a sewage source, the sediments turned septic (highly-polluted) to the extent that they killed all bottom life and excluded the introduction of organisms from other areas.

Earlier, Sarma \& Ganapati (1975) listed the occurrence of 38 species of polychaetes in the northern arm of the harbour (corresponding to Stations $\mathrm{Vb}$ and $\mathrm{Vc}$ ). They also stated that the mangrove swamp in that locality was "relatively free of pollution", when they carried out their investigation in 1972. Of the 38 forms listed by Sarma \& Ganapati (op. cit.), the author came across only 12 species, when he carried out his study in 1976 (Raman \& Ganapati, 1986). The disappearance of other species reported by Sarma \& Ganapati (1975) was considered to be due to an increase in pollution during the intervening years. More recent findings showed that further changes have occurred (Bismillah, 1986). Of the 11 species of polychaetes encountered during the 1976 study, only 4 forms were found by Bismillah (op. cit.), the others being absent. At St.Vb,

Table 3. Water and benthic characteristics at St.Vb in 1976 and 1985-1986. N.D.: Not detected. Figures in parentheses denote median values unless stated otherwise

\begin{tabular}{|lcc|}
\hline Characteristics & $\begin{array}{c}1976 \\
\text { (Raman, 1980) }\end{array}$ & $\begin{array}{c}\text { 1985-1986 } \\
\text { (Bismillah, 1986) }\end{array}$ \\
\hline Dissolved oxygen $(\mathrm{mg} / \mathrm{l})$ & N.D.-11.4 & N.D.-6.2 \\
Nitrate-nitrogen $(\mathrm{mg} / \mathrm{l})$ & $(5.4)$ & (N.D.) \\
& N.D.-1.1 & N.D.-0.271 \\
Sediment organic matter (\%) & $(0.09)$ & $($ N.D.) \\
Number of benthic species & $1.19-3.90$ & $0.91-11.31$ \\
Numerical abundance & $(2.53)$ & $(3.72)$ \\
(Mean: Nos./0.05 $\left.\mathrm{m}^{2}\right)$ & 5 & 3 \\
Margalef diversity $(d)$ & $23-7493$ & $10-14295$ \\
Shannon-Wiener $\left(\mathrm{H}^{\prime}\right)$ index & $(879)$ & $(925)$ \\
M & 0.31 & 0.24 \\
\hline
\end{tabular}


Capitella capitata and Nereis glandicincta that were dominant during the 1976 study $(95 \%)$ had almost disappeared by $1985-1986(<3 \%)$, and a tubificid worm Monopylephorus sp. now occurs there. Similarly, at St.Vc the two earlier dominants, Diopatra neapolitana and $N$. glandicincta, have been replaced by $C$. capitata. Marked changes occurred in water quality and sediments during this time (Table 3 ).

The harbour had also witnessed significant changes in the composition and abundance of fouling communities. In 1958, Ganapati and others reported as many as 43 species of fouling organisms in the harbour. At present, several of these forms have either totally disappeared from those localities or now occur in reduced numbers. The examples include certain serpulid polychaetes, an amphipod, a barnacle, and oyster. These organisms which once flourished have faded out now, evidently due to changes in water quality. Perhaps the most significant finding which emerged during recent years relates to the introduction, success and spread of an exotic dressinid bivalve Mytilopsis sallei in the harbour (Satyanarayana Rao et al., 1989). By the nature of its dominance, M. sallei has proved to be a serious competitor to the many endemic foulers in the harbour.

Pearson (1975) made a detailed investigation on the benthic fauna in Loch Eil, Scotland, over a period of ten years, in relation to pollution caused by pulp-mill wastes in that area. In the highly polluted Tees estuary, a comparison of surveys carried out in 1935 with others in 1971 and 1973 showed that there was a dramatic reduction in the species of bivalves and polychaetes, caused by pollution (Gray, 1976). More recently, Reish et al. (1980) discussed results of 28 years of continuous monitoring of benthic biological conditions of the Los Angeles-Long Beach harbours, California, in relation to pollution. Local harbour findings have revealed that, prior to the construction of the outer harbour, the environmental conditions remained comparatively unpolluted, as indicated by the low nutrient levels and a great diversity of macrobenthic life and other organisms. This is undoubtedly due to the flushing out of wastes by tides into the sea, resulting in their quick dispersion. After 1976 there was, however, considerable deterioration in water quality. This was evident from an increase in the concentration of inorganic nitrogen and phosphorus. Phytoplankton blooms have become a common feature, as well as mass fish kills. In the harbour, species that, earlier on, inhabited unpolluted or semi-polluted environments are gradually replaced by pollution tolerant forms. In the interior channels, where the effect of pollution is relatively high, the bottom is devoid of any macroscopic life for some distance from the outfall. To sum up - a combination of factors, including rich nutrient supplies arising from waste discharges, coupled with sluggish circulation and efficient nutrient regeneration mechanisms have turned Visakhapatnam harbour into a highly eutrophic environment, capable of supporting rich biotic communities. Over a period of several years, the harbour seems to have acted as a sink for a variety of waste additives, resulting in the observed changes.

Acknowledgements. Many funding agencies such as INSA, CSIR, DOEn and UGC, New Delhi, enabled me to carry out investigations in Visakhapatnam Harbour over the past several years. Grateful thanks are due to them. I also wish to thank the Visakhapatnam Port Trust Authority for their kind help. Successive Heads of the Department of Zoology in the University have generously extended all facilities. This paper was presented at an International Symposium on "100 years of Biologische Anstalt Helgoland - A Challenge to Marine Biology in a Changing World", Helgoland, September, 1992. I am grateful to Professor W. Gunkel, Director, and Dr. M. R. Kirchner, Adviser to visiting scientists, of the Biologische Anstalt Helgoland, for their kind assistance. 


\section{LITERATURE CITED}

APHA (Ed.), 1971. Standard methods for the examination of water and wastewaster. American Public Health Association, Washington, $874 \mathrm{pp.}$

Bismillah Shaik, 1986. Ecology of macrobenthos in relation to pollution in the north arm in Visakhapatnam harbour. Thesis, Andhra Univ., Waltair, 59 pp.

Eppley, R. W. \& Weiler, C. S., 1979. The dominance of nanoplankton as an indicator of marine pollution: a critique. - Oceanologica Acta 2, 241-245.

Fanuko, N., 1984. The influence of experimental sewage pollution on lagoon phytoplankton. - Mar. Pollut. Bull. 15, 195-198.

Food and Agricultural Organisation (Ed.), 1975. Manual of methods in aquatic environment research. Part I. Methods for detection, measurement and monitoring of water pollution. - FAO Fish. tech. Pap. 137, 1-233.

Ganapati, P. N., 1969. Biology of pollution in Visakhapatnam harbour. - Mar. Pollut. Bull. 166, 1-3.

Ganapati, P. N. \& Raman, A. V., 1973. Pollution in Visakhapatnam harbour. - Curr. Sci. 42, 490-492.

Ganapati, P. N. \& Raman, A. V., 1979. Organic pollution and Skeletonema blooms in Visakhapatnam harbour. - Indian J. mar. Sci. 8, 184-187.

Ganapati, P. N., Lakshmana Rao, M. V. \& Nagabushanam, R., 1958. Biology of fouling in the Visakhapatnam harbour. - Andhra Univ. Mem. Oceanogr. 62, 193-209.

Gaudette, H. E., Wilson, R. G., Toner, L. \& Folger, D. W., 1974. An in-expensive titration method for the determination of organic carbon in recent sediments. - J. sedim. Petrol. 44, 249-253.

Gray, J. S., 1976. The fauna of the polluted river Tees estuary. - Estuar. coast. mar. Sci. 4, 653-676.

Holme, N. A. \& McIntyre, A. D., 1971. Methods for the study of marine benthos. Blackwell, Oxford, $387 \mathrm{pp}$.

Ketchum, B. H., 1973. Ecological effects of marine pollution. Marine Biological Association of India, Cochin, 7-28.

Mahoney, J. B. \& Mclaughlin, J. J. A., 1979. Salinity influence on ecology of phytoflagellate blooms in lower New York Bay and adjacent waters. - J. exp. mar. Biol. Ecol. 37, 213-223.

Pearson, T. H., 1975. The benthic ecology of Loch Linhe and Loch Eil, a sea-Loch system on the west coast of Scotland. IV. Changes in the biotic fauna attributable to organic enrichments. - J. exp. mar. Biol. Ecol. 20, 1-41.

Pearson, T. H. \& Rosenberg, R, 1978. Macrobenthic succession in relation to organic enrichment and pollution of the marine environment. - Oceanogr. mar. Biol. 16, 229-311.

Phaniprakash, K., 1989. Phytoplankton ecology in relation to pollution in Visakhapatnam harbour, Bay of Bengal. Thesis, Andhra Univ. Waltair, $180 \mathrm{pp}$.

Prasada Reddy, B. R., 1986. Studies on some physico-chemical parameters of harbour and coastal waters of Visakhapatnam (Bay of Bengal). Thesis, Andhra Univ., Waltair, 195 pp.

Raman, A. V., 1980. Ecobiology of pollution in Visakhapatnam harbour (Bay of Bengal). Thesis, Andhra Univ., Waltair, $171 \mathrm{pp}$.

Raman, A. V. \& Ganapati, P. N., 1983. Pollution effects on ecobiology of benthic polychaetes in Visakhapatnam harbour (Bay of Bengal). - Mar. Pollut. Bull. 14, 46-52.

Raman, A. V. \& Ganapati, P. N., 1986. Benthic polychaete macrofauna and pollution in Visakhapatnam harbour, India. In: Indian Ocean - biology of benthic marine organisms. Ed. by M.-F. Thompson, R. Sarojini \& R. Nagabhushanam. Oxford \& IBH Publishing, New Delhi, 463-484.

Raman, A. V. \& Phaniprakash, K., 1989a. Phytoplankton ecology in relation to pollution in Visakhapatnam harbour, east coast of India. - Asian mar. Biol. 6, 161-166.

Raman, A. V. \& Phaniprakash, K., 1989b. Phytoplankton in relation to pollution in Visakhapatnam harbour, east coast of India. - Indian J. mar. Sci. 18, 33-36.

Rama Raju, V. S., Sarma, V. V., Narasimha Rao, T. V. \& Vijaya Kumar, R., 1987. Variation of physicochemical characteristics with tide in Visakhapatnam harbour, east coast of India. - Indian J. mar. Sci. 16, 218-222.

Reish, D. J., Soule, D. F. \& Soule, J. D., 1980. The benthic biological conditions of Los Angeles. Long Beach harbours: Results of 28 years of investigations and monitoring. - Helgoländer Meeresunters. 34, 193-205.

Richards, F. A. \& Thompson, T. G., 1952. The estimation and characterisation of plankton populations by pigment analyses. - J. mar. Res. 11, 156-171. 
Sarma, A. L. N. \& Ganapati, P. N., 1975. Meiofauna of the Visakhapatnam harbour in relation to pollution. - Bull. Dep. mar. Sci. Univ. Cochin 7, 243-255.

Sarma, V. V., Raju, G. R. K. \& Bose Babu, T., 1982. Pollution characteristics and water quality in the Visakhapatnam harbour. - Mahasagar 15, 15-22.

Satyanarayana Rao, K., Srinivasan, V. \& Balaji, M., 1989. Success and spread of the exotic fouling bivalve Mytilopsis sallei (Recluz) in Indian waters. - Spec. Publ. Asian Fish. Soc. 1, 125-127.

Sournia, A. (Ed.), 1978. Monographs on oceanographic methodology - phytoplankton manual. UNESCO, Paris, 337 pp.

Stockner, J. G. \& Cliff, D. B., 1979. Phytoplankton ecology of Vancouver harbour. - J. Fish. Res. Bd Can. 36, 1-10.

Strickland, J. D. H. \& Parsons, T. R., 1968. A practical handbook of sea water analysis. - Bull. Fish. Res. Bd Can. 167, 1-311.

Tsuruta, A. \& Yamada, M., 1980. Hydrological and biological observations in Dokai Bay, Northern Kyushu. III. Phytoplankton as a biological indicator of eutrophication. - J. Shimonoseki Univ. Fish. 29, 103-111.

Umamaheswara Rao, M. \& Mohanchand, V., 1988. Water quality characteristics and phytoplankton of polluted Visakhapatnam harbour. - Mar. environ. Res. 25, 423-430. 